DOI: 10.17516/1997-1370-0795

УДК 94

\title{
21st-Century Archaeological Discoveries of the Early Nomadic Cultural Remains - Centered in the Middle Section of the Great Wall Area in Inner Mongolia Autonomous Region
}

\author{
Cao Jianen and Sun Jinsong* \\ Institute of History of Science and Technology \\ Inner Mongolia Normal University \\ Institute of Cultural Relics and Archaeology \\ Inner Mongolia Autonomous Region
}

Received 22.05.2021, received in revised form 04.06.2021, accepted 06.07.2021

\begin{abstract}
Since the beginning of the 21 st century, eight early nomadic cultural remains located in Xinzhouyaozi Village, Xiaoshuanggucheng Village, and Xindianzi Town, have been discovered in Manhan Mountain, Hunhe River and two other districts in the middle section of the Great Wall area in Inner Mongolia Autonomous Region. The new discoveries have crucial academic significance to the study of the formation of nomads, cultural exchanges, and the culture of steppe nomads, in terms of burial styles, animal sacrifice customs, and characteristics of grave goods.
\end{abstract}

Keywords: Great Wall area, nomadic culture, new archaeological discoveries.

Research area: history and archaeology

Citation: Cao Jianen, Sun Jinsong (2021). 21st-century archaeological discoveries of the early nomadic cultural remains - centered in the middle section of the Great Wall area in Inner Mongolia Autonomous Region. J. Sib. Fed. Univ. Humanit. soc. sci., 14(8), 1121-1138. DOI: 10.17516/1997-1370-0795.

(C) Siberian Federal University. All rights reserved

* Corresponding author E-mail address: sjxx@imnu.edu.cn; xzxx@imnu.edu.cn 


\title{
Современные археологические находки
}

\section{остатков культуры ранних кочевников средней части района Великой Китайской стены в автономном районе «Внутренняя Монголия»}

\author{
Цао Цзяньэнь, Сунь Цзиньсун \\ Институт истории науки и техники \\ Национальный университет Внутренней Монголии \\ Институт культурных реликвий и археологии \\ Внутренняя Монголия
}

\begin{abstract}
Аннотация. С начала 21 века в горах Маньхань, на реке Хунхэ и в двух других местностях средней части района Великой Китайской стены автономного района «Внутренняя Монголия» были обнаружены восемь культурных останков ранних кочевников, расположенных в деревнях Синьчжоуяоцзы, Сяошуангучэн и городе Синьдяньцзы. Новые открытия имеют важное значение для изучения истории и культуры степных кочевников (включая межкультурный обмен) с точки зрения стилей погребения, обычаев жертвоприношения животных и характеристик погребальных принадлежностей.
\end{abstract}

Ключевые слова: район Великой Китайской стены, кочевая культура, новые археологические открытия.

Научная специальность: 07.00. 00 - история и археология

\section{Introduction}

The Great Wall area in North China is the intersection where the steppe nomadic culture meets the agricultural civilization of the Central Plains. The area serves as a boundary between agrarian and pastoral societies, and also a key place for the two economies to meet and merge, representing a balance of «force» formed by the two contending cultures. The middle section of the Great Wall area in Inner Mongolia Autonomous Region mainly covers the Manhan Mountain, Ordos Plateau, Tumochuan Plain, Hunhe River Basin, and Huangqihai Area. As the Ordos bronzes, featuring the Eurasian Steppe «animal style,» were primarily unearthed in the Ordos area between the 1950s and 1960s, such remains have been drawing extensive attention and leading to continuous research among scholars both at home and abroad. In the 1970s and 1980s, along with the archaeological excavations of Taohongbala Cemetery, Maoqinggou Cemetery, and Xiyuan Cemetery, the studies of the early nomadic remains in the middle section of the Great Wall area in Inner Mongolia Autonomous Region saw fundamental changes in both depth and breadth. As a series of academic achievements have been widely recognized by the academia at home and abroad, heated debates also arose on subjects such as the division of cultural systems, human migration, and the integration of agricultural and pastoral cultures. Since entering in the 21 st century, new archaeological discoveries of the early nomadic cultural remains in the middle section of the Great Wall area in Inner Mongolia have presented new scientific evidence for in-depth discussions about the foregoing issues. This paper will introduce the early nomadic cultural remains discovered in the middle section of the Great Wall area of the Inner Mongolia Autonomous Region and carry on in-depth discussions accordingly on related issues.

\section{Overview of the new archaeological discoveries}

The early nomadic remains discovered in the 21 st century in the middle section of the 
Great Wall area in Inner Mongolia are centered in the Manhan Mountain area, Ordos area, Hunhe River area, and Huangqihai area (Figure 1). The cemeteries are introduced as follows according to areas.

\section{(A) Manhan Mountain Area}

A total of three early nomadic cemeteries were discovered in the area, namely Xinzhouyaozi, ${ }^{1} \quad$ Xiaoshuanggucheng, ${ }^{2}$ and Shuiquan. ${ }^{3}$

\section{Xinzhouyaozi Cemetery}

With a total area of 15,000 square meters, Xinzhouyaozi Cemetery is located in the sunny slop that is about 1 kilometer north of Xinzhouyaozi Village, Yongxing Town, Liangcheng County, Ulanqab City. In 2003, the Institute of Cultural Relics and Archaeology of Inner Mongolia Autonomous Region carried out a proactive excavation at the site and discovered a total of 69 tombs.

All tombs from Xinzhouyaozi Cemetery are vertical earthen pits (110-250 centimeters in length and $40-110 \mathrm{~cm}$ in width). The tombs all face northeast with an orientation of 50-101 degrees. Second-tier ledges and head niches are commonly seen in the tombs, usually with a pottery ware in the head niche.

\footnotetext{
Institute of Cultural Relics and Archaeology of Inner Mongolia Autonomous Region 内蒙古自治区文物考古研究所. 2016. Daihai diqu Dongzhou muqun fajue baogao 岱海地区 东周墓群发掘报告 (The Excavation of Eastern Zhou Cemetery in Daihai Lake Area). Kexue chubanshe, Beijing; Institute of Cultural Relics and Archaeology of Inner Mongolia Autonomous Region 内蒙古自治区文物考古研究所. 2009. «Neimenggu Liangcheng xian Xinzhouyaozi mudi fajue jianbao» 内蒙古凉城县忻州窑子墓地发掘简报 (The Excavation of Xinzhouyaozi Cemetery in Liangcheng County, Inner Mongolia Autonomous Region). Kaogu 考古 (Archaeology) No. 3 .

2 See [1] above.

3 Institute of Cultural Relics and Archaeology of Inner Mongolia Autonomous Region 内蒙古自治区文物考古研究所. 2016. Daihai diqu Dongzhou muqun fajue baogao 岱海地区 东周墓群发掘报告 (The Excavation of Eastern Zhou Cemetery in Daihai Lake Area). Kexue chubanshe, Beijing; Institute of Cultural Relics and Archaeology of Inner Mongolia Autonomous Region 内蒙古自治区文物考古研究所. 2012. «Liangcheng xian Shuiquan Dongzhou mudi fajue jianbao» 凉城县水泉东周墓地发掘简报 (The Excavation of Shuiquan Cemetery of the Eastern Zhou Dynasty in Liangcheng County, Inner Mongolia Autonomous Region). Caoyuan wenwu 草原文物 (Steppe Cultural Relics) No. 1.
}

No burial containers were found, except a stone outer coffin in one tomb. An individual was laid out in an extended supine position in each tomb. Tomb chamber floors are mostly higher on the foot side and lower on the head side.

Animal sacrifices were prevalent in Xinzhouyaozi Cemetery, which were usually found from the filling dirt at the east end of the tomb and above the skull of the human remains. Most of the unearthed animal remains were skulls, parietal bones, and pedal bones of horses, cattle, sheep/goats, swine, and dogs. All sacrificed animals were placed upside down, that is, the mandibles were facing upward, the snouts were in the direction of human skulls, and small bones such as pedal bones, coronary bones were placed in the maxilla of the same animal. The number of animals buried in each tomb varies, with the most being at least 13. Scapulae or ribs of cattle or sheep/goats were found around human chest or abdomen, which might be a special sacrifice different from the regular one. The combinations of sacrificed animals fall into six categories, which are horses, cattle, sheep/ goats; horses, sheep/goats; cattle, sheep/goats, swine, dogs; cattle, sheep/goats, dogs; sheep/ goats; dogs. Sheep/goats account for the most with an equal number of sheep and goats. The number of cattle ranks second, followed by horses, swine, and dogs successively.

The grave goods unearthed from Xinzhouyaozi Cemetery consist mainly of bronzes, and a certain number of pottery wares, horns, clams, stones, jade and so on. Among them, each tomb has one pottery ware discovered, most of which was placed in the head niche. The pottery wares consist mainly of double-eared guan-jars with necks, plain surface guan-jars without ears, cordpatterned guan-jars without ears, followed with a small number of double eared guanjars without necks, guan-jars with four lugs, and single-eared guan-jars were also discovered. Some of the pottery ware mouths have a pair of symmetrical holes, which might be designed for carrying and moving. This cemetery features a large number of pottery wares with sharp shoulders. Most of the 


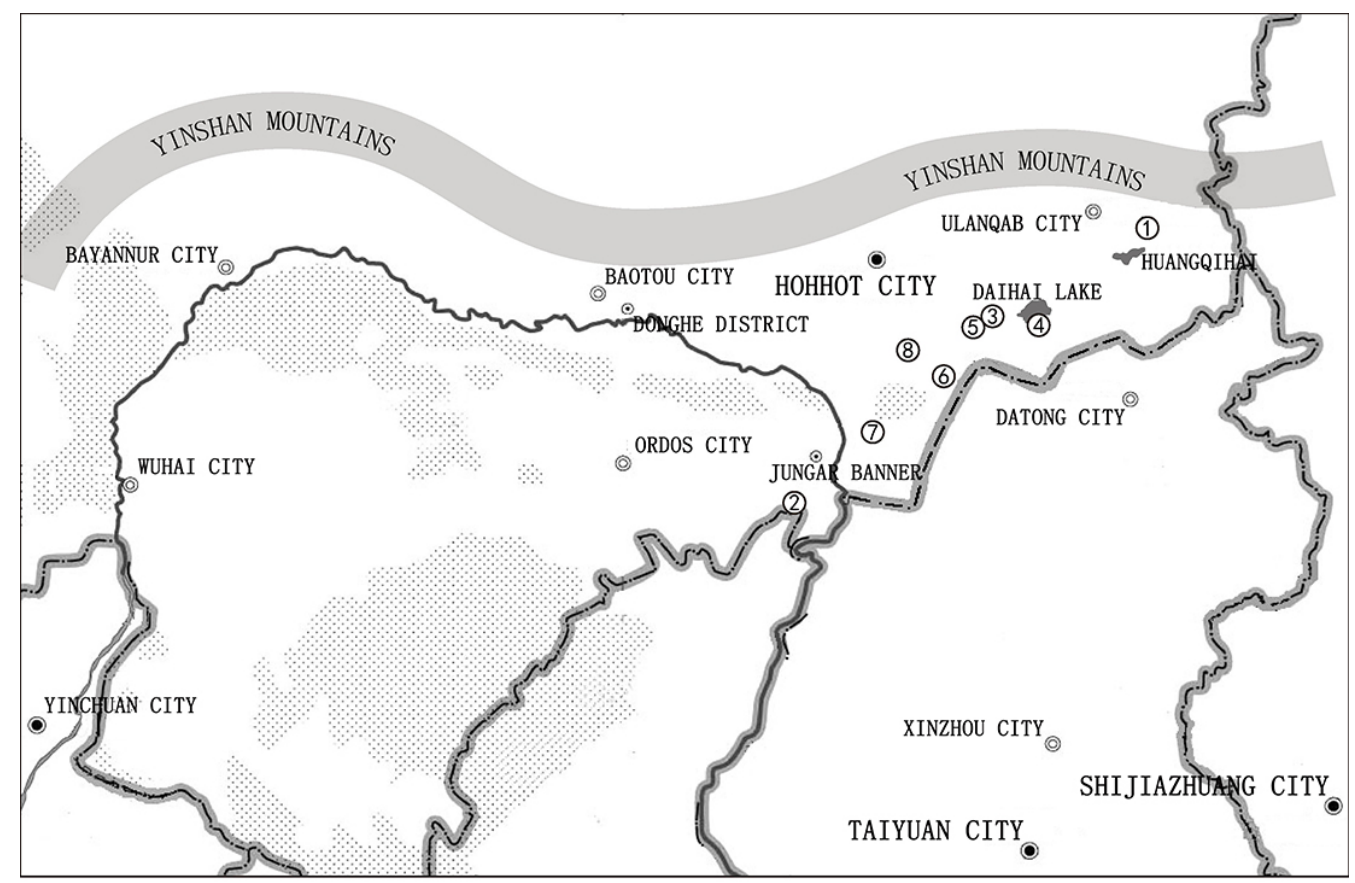

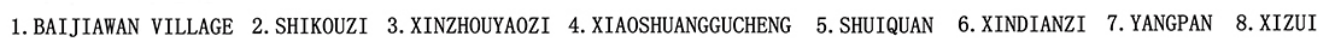

Figure 1. Distribution of the newly discovered early nomadic remains in the middle section of the Great Wall area in Inner Mongolia Autonomous Region

bronzes are ornaments featuring various tubular ornaments, single-bird-shaped plaques, and double row of beads. No weapons, tools, and harnesses were found, and only a few living utensils have been discovered. Among the bronze ornaments, belt accessories are the most abundant. Ring-shaped belt buckles, linked beads, short tubes, rings, single birdshaped plaques, double bird-shaped plaques were designed to be mixed and matched. And a small number of ornaments were found in the form of bullet-clip-shaped belts, buckles, deer-patterned plaques, chains, squaredspiral-patterned plaques, etc. A large number of short tubular ornaments can be divided into flat tubes, drum-shaped tubes, straight tubes and the like. The flat tubular ornaments are decorated with «人»-shaped patterns, reflecting the unique cultural characteristics of the cemetery. From the archaeological excavation site, the short tubular ornaments were threaded on leather strips to form bronze chains to connect with other objects. The ends of the bronze chains were generally connected with a number of rings, which can reach up to four. The bronze bells at the ends of the bronze chains were probably special things for wizards. In addition, popular earrings are in spring style; various buckles and pins were seen as clothing accessories; cross-shaped jiejue-strap-crossings, round mirrors, mirrors with nob-shaped handles, etc. were used as living utensils. All of these ornaments reflect a unique cultural style.

Besides bronzes, a certain amount of grave goods made from other materials were unearthed in Xinzhouyaozi Cemetery; the bone artifacts consist mainly of bone arrowheads, followed by a small number of thumb rings, belt buckles, arrow nocks, etc.; clam rings and cowrie shells are rare. In addition to whetstone, unearthed jade/stone artifacts contain turquoise beads, agate beads, agate tubes and dressed stone beads, which were primarily used to mix and match to form multicolored necklaces (Figure 2). 


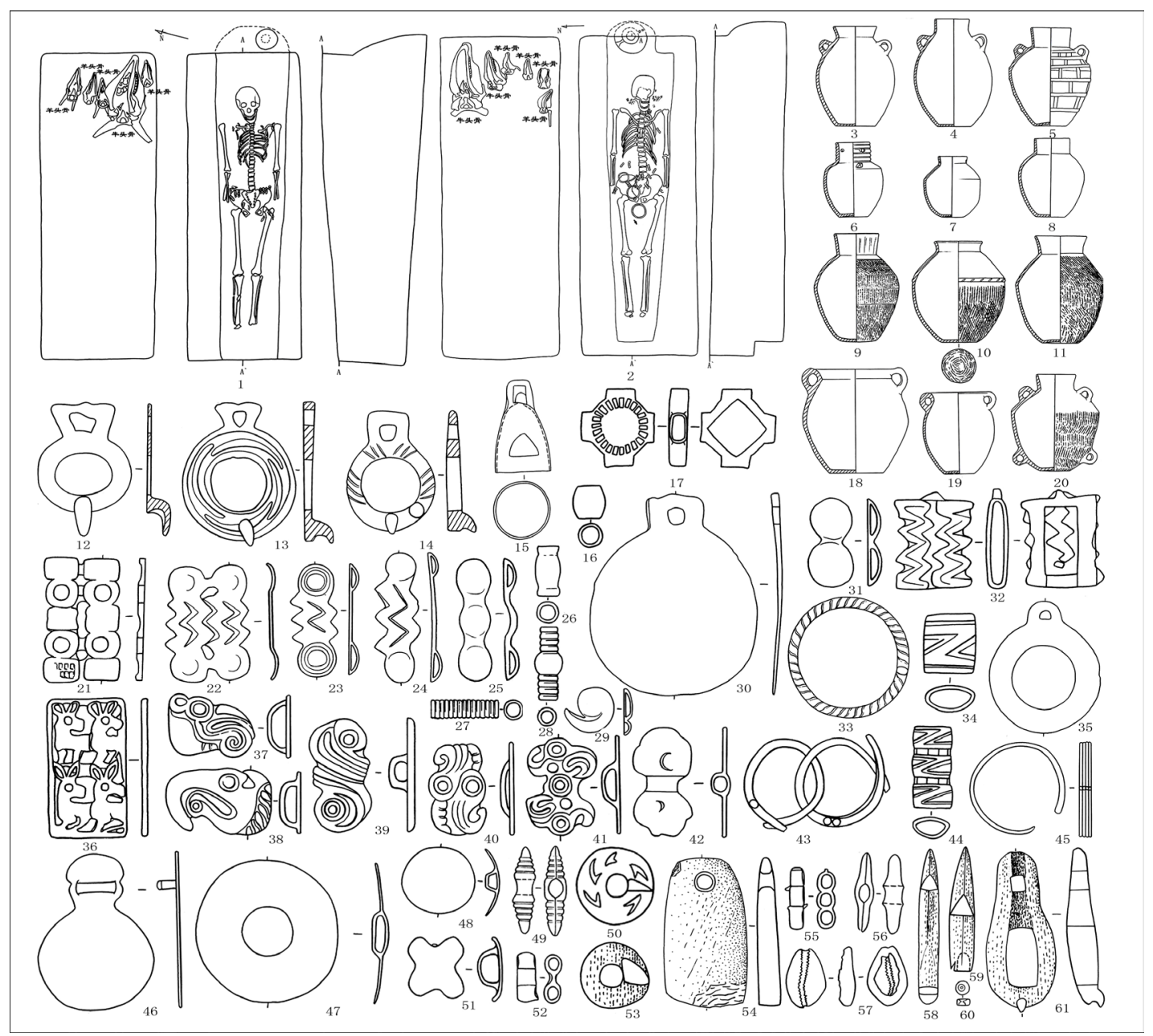

Figure 2. Line drawings of typical remains and artifacts of Xinzhouyaozi Cemetery

1. Plan view and profile of Tomb M10 2. Plan view and profile of Tomb M33 3-5. Double-eared guan-jars with necks (03LBM34:1, 03LBM27:1, 03LBM2:1) 6-8. Plain surface guan-jars without ears

(03LBM11:1, 03LBM3:1, 03LBM48:1) 9-11. Cord-patterned guan-jars without ears (03LBM5:1, 03LBM67:1, 03LBM64:1) 12-14. Ring buckles (03LBM45:2, 03LBM28:2, 03LBM66:2) 15. Bronze bells (03LBM20:3)

16, 26, 28. Drum-shaped tubular ornaments (03LBM45:8, 03LBM56:24, 03LBM22:12) 27. Straight tubular ornaments (03LBM34:11) 17. Jieyue-strap crossing (03LBM59:16) 18-19. Double-eared guan-jars without necks (03LBM11:2, 03LBM21:1) 20. Guan-jar with four lugs (03LBM31:1) 21-22. Double row of beads (03LBM9:7, 03LBM37:5) 23-25, 31. Single row of beads (03LBM38:4, 03LBM9:5, 03LBM33:17, 03LBM34:6) 29. Buckle ornaments (03LBM28:28) 30, 46. Mirror-shaped ornaments (03LBM23:2, 03LBM1:2) 32. Bullet-clip-shaped ornaments (03LBM20:9) 33, 35. Rings (03LBM64:10, 03LBM67:9) 34, 44. Flat tubular ornaments (03LBM2:7, 03LBM13:7) 36. Deer-patterned plaques (03LBM59:1) 37, 38.

Single-bird-shaped plaques (03LBM27:2, 03LBM28:9) 39-42. Double-bird-shaped plaques (03LBM36:5, 03LBM20:5, 03LBM53:6, 03LBM20:7) 43, 45. Spring-typed earrings (03LBM46:3-4, 03LBM32:4)

47-48, 51. Buckle ornaments (03LBM67:5, 03LBM29:31, 03LBM9:9) 49, 52, 55, 56. Pins (03LBM10:12,

03LBM28:45, 03LBM25:3, 03LBM33:72) 50. Buckle ornaments (03LBM61:6) 53. Bone buckle (03LBM18:4) 54. Whetstone (03LBM14:1) 57. Cowrie shell ornaments (03LBM37:16) 58-59. Bone arrowheads (03LBM18:6, 03LBM45:15) 60. Agate ornaments (03LBM33:94) 61. Bone belt buckle (03LBM11:5) 


\section{Xiaoshuanggucheng Cemetery}

Xiaoshuanggucheng Cemetery is located in the southeast of Xiaoshuanggucheng Village, Basumu Township, Liangcheng County, Ulanqab City, and on the sunny hillside of the northern slope of Wangmu Mountain, with a total area of 7,500 sq.m. In 2003, the Institute of Cultural Relics and Archaeology of Inner Mongolia Autonomous Region carried out a proactive excavation at the site and discovered a total of 14 tombs.

The burial styles of the Xiaoshuanggucheng tombs can be divided into two major categories: vertical earthen pit tombs and cave tombs with side chambers, and the latter are dominant. The vertical earthen pit tombs are mostly rectangular with straight walls and flat bottoms. The tombs are eastward with a length of $180-215 \mathrm{~cm}$ and a width of $40-60 \mathrm{~cm}$. All tombs were primary burials with single interment. Each individual was laid out in an extended supine position. The tomb entrance corridors of the cave tombs with side chambers are mostly rectangular, having straight walls and flat bottoms. The tombs are eastward with a length of 105-205 cm and a width of 40-80 cm. The tomb chamber is located on the left side of the entrance corridor, the length of the side chamber is basically the same as the entrance corridor. Each individual with an extended supine position was interred in a tomb chamber. No burial containers were found in these primary burials.

A large number of animal sacrifices were found in Xiaoshuanggucheng Cemetery, most of which were placed in the bottom of the entrance corridor in cave tombs or filling dirt above the skull in vertical earthen pit tombs. The skulls of horses, cattle, and sheep/goats were dominant and a few animal pedal bones or coronary bones were also seen, which were placed upright, i. e. the mandibles were facing downward, animal snouts were in the direction of human skulls. The number of animals buried in each tomb varies, with the most being at least 19, and an average of 4.8 animals per tomb. The skulls of large animal sacrifices, such as horses and cattle, are mostly located in the east front of the sacrifice combination, or near the human remains. The combinations of sacrificed animals fall into three categories, which are horses, cattle, sheep/goats; horses, cattle; sheep/goats. The number of sheep/goats ranks first, followed by cattle and horses successively.

The grave goods of Xiaoshuanggucheng Cemetery consist mainly of bronzes, followed by pottery wares, and a few artifacts of gold, bone, and stone/jade were also discovered. Pottery guan-jars with cord patterns and bulging bellies and double-eared guan-jars were recovered, and the former are dominant. Among the bronzes, ornaments are prevailing. Besides earrings, stick-shaped ornaments, beaded pendants, square pendants, arc-shaped necklaces, clothing buttons, the rest are all belt ornaments, which are best featured in double-bird patterns and animal shapes. A small number of drumshaped tubular ornaments, straight tubular ornaments, rings, bells, etc. were also recovered. No ring-shaped belt buckles were found. Tigershaped belt ornaments are dominant, especially in the form of tiger-eating-sheep, tiger-eatingwolf, and double-tigers, etc., which were exquisite and ingeniously designed. The doublebird plaques are decorations embellished on belts, generally no more than four on one belt. In addition, no bronze weapons were found. Only ring pommel knives, knives with irregular holes were discovered as tools. The living utensils consist primarily of mirror-shaped ornaments with bridge-shaped nobs and bronze awls.

Most of the bone artifacts are arrowheads, and a small number of bone awls, mabiaohorse cheek pieces were found. As for gold objects, only trapezoidal ornaments were recovered. The jade/stone artifacts consist mainly of agate and turquoise beads worn around necks (Figure 3).

\section{Shuiquan Cemetery}

Shuiquan Cemetery is located on the sunny hillside of the south foothill of the northern Manhan Mountain in Shuiquan Village, Yongxing Town, Liangcheng County, Ulanqab City, with a total area of about 8,400 sq.m. In 2008, the Institute of Cultural Relics and Archaeology of Inner Mongolia Autonomous Region carried out a proactive excavation at 


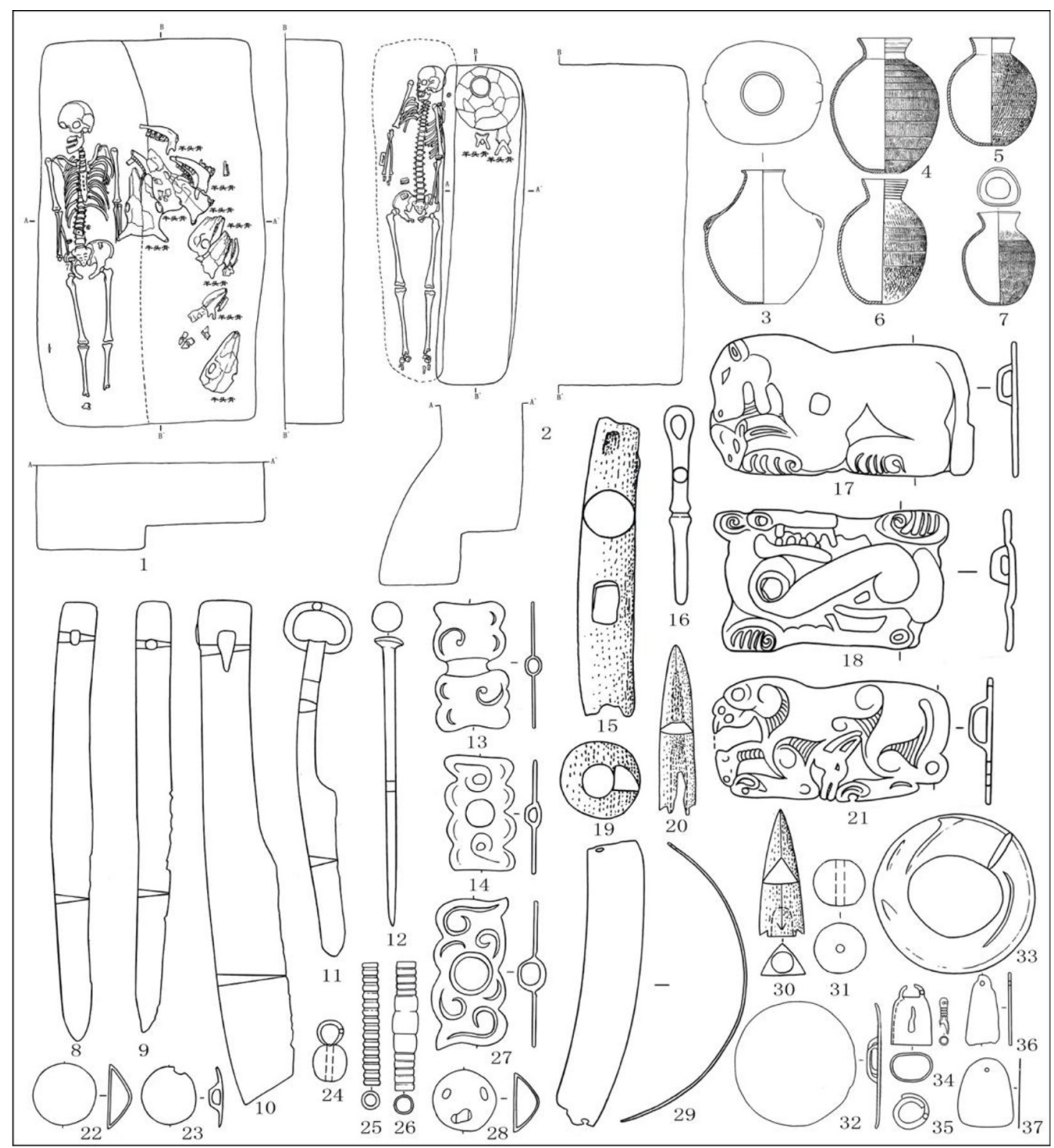

Figure 3. Line drawings of typical remains and artifacts of Xiaoshuanggucheng Cemetery 1. Plan view and profile of Tomb M5 2. Plan view and profile of Tomb M13 3. Double-eared hujar (03LXM13:1) 4-7. Guan-jars with cord patterns and bulging bellies (03LXM1:1, 03LXM11:1,

03LXM7:1, 03LXM4:1) 8-10. Knives with irregular holes (03LXM9:3, 03LXM15:1, 03LXM2:1)

11. Ring pommel daggers (03LXM12:1) 12. Awls (03LXM12:2) 13-14, 27. Double-bird-patterned plaques (03LXM2:2, 03LXM1:2, 03LXM3:5) 15. Bone biao-horse cheek piece (03LX M9:21) 16. stick-shaped ornaments (03LXM11:9) 17-18, 21. Tiger-shaped belt ornaments (03LXM11:2, 03LX M13:2, 03LXM9:2) 19. Bone buckle (03LXM2:4) 20, 30. Bone arrowheads (03LXM4:4, 03LXM11:11) 22-23, 28. Buckle ornaments (03LXM11:5, 03LXM4:3, 03LXM7:2) 24. Beaded pendant (03LXM6:6)

25. Straight tubular ornaments (03LXM3:11) 26. Drum-shaped tubular ornaments (03LXM5:7)

29. Arc-shaped necklace (03LXM6:2) 31. Agate beads (03LXM6:8) 32. Mirror-shaped ornaments (03LXM3:2) 33. Ring-shaped ornament (03LX M9:11) 34. Bell (03LXM3:3) 35. Earring (03LXM10:4) 36. Square-shaped pendant (03LXM3:13) 37. Square-shaped gold pendant (03LXM6:7) 
the site and discovered a total of 27 tombs, which can be divided into Type A and B according to the burial styles and grave goods combinations.

Type A tombs in Shuiquan Cemetery are all vertical earthen pit tombs with a direction of east-west. Facing east with shallow pits, the tombs have straight walls and flat bottoms. Wooden inner and outer coffins were used in some tombs. All tombs were primary burials with single interment. Animal sacrifices were found from the filling dirt at the east end of the tomb or near the human remains at the tomb bottom. Most of the animal remains were skulls, coronary bones of cattle and sheep/ goats, which were placed upright with animal snouts in the direction of human skulls. The combinations of sacrificed animals fall into two categories, which are cattle, sheep/goats; sheep/goats. One guan-jar with a cord pattern and bulging belly and one guan-jar with a plain surface and bulging belly were found. Besides that, iron artifacts are dominant. However, due to serious corrosion, iron artifacts are difficult to identify. The identifiable iron artifacts include ring pommel swords, crane's beak axes [resemble European war hammers - Trans.], rectangular iron plaques, plaques with double-bird pattern, braceletshaped rings, disc-shaped rings, etc.; the unearthed bronze artifacts are fewer, including double-bird patterned plaques, disc-shaped rings, and buckle ornaments, etc.; in addition, there are bone nocks, bone beads, liuli-glazed dragonfly eye beads, and necklaces made with dressed stone beads, agate beads, turquoise beads, and glass tubes.

Among Type B tombs in Shuiquan Cemetery, vertical earthen pit tombs with a direction of north-south are dominant and the direction of east-west coexist. The tomb pits are deep, and wooden burial containers are prevalent. These tombs are primary burials with single interment having heads to the east or north; It was found that sacrificed sheep/goats' scapulae and limb bones were placed above or on one side of human remains. Fewer grave goods were discovered, including a small amount of iron belt hooks, bronze awls, bone hairpins, etc. (Figure 4).

\section{(B) Hunhe River Basin}

A total of three early nomadic cemeteries were discovered in this area, namely Xindian$\mathrm{zi}^{4}{ }^{4}$ Yangpan, ${ }^{5}$ and Xizuizi cemeteries. ${ }^{6}$

\section{Xindianzi Cemetery}

With a total area of 250,000 sq.m, Xindianzi Cemetery is located in the sunny hillside of the northern bank of the Hunhe River in the northwest of Xiaobanshen Village, Xindianzi Township, Horinger County, Hohhot City. In 1999, the Institute of Cultural Relics and Archaeology of Inner Mongolia Autonomous Region carried out a proactive excavation at the site and discovered a total of 56 tombs.

Vertical earthen pit tombs and cave tombs are dominant in Xindianzi Cemetery, which account for $77 \%$ of the total number of tombs; cave tombs with side chambers ranked number two, accounting for only $23 \%$ of the total number of tombs. The plan views of tombs are mostly rectangular and rarely trapezoidal or irregular. The lengths are generally between 110-390 cm, the widths are between 50-210 $\mathrm{cm}$, and the depths are between $10-190 \mathrm{~cm}$. All tombs have no burial containers. Single interment with extended supine position was dominant. It is rare to see an individual placed on the side with limbs bent. Individuals were buried with the head to the northeast, and the tomb chamber floors are mostly higher on the foot side and lower on the head side.

\footnotetext{
4 Institute of Cultural Relics and Archaeology of Inner Mongolia Autonomous Region 内蒙古自治区文物考古研究所. 2009. «Neimenggu Helinge’er xian Xindianzi mudi fajue jianbao» 内蒙古和林格尔县新店子墓地发掘简报 (The Excavation of Xindianzi Cemetery in Horinger County, Inner Mongolia Autonomous Region). Kaogu 考古 (Archaeology) No.3.

5 Institute of Cultural Relics and Archaeology of Inner Mongolia Autonomous Region 内蒙古自治区文物考古研究 所. 2018. «Neimenggu Qingshuihe xian Yangpan Dongzhou mudi fajue jianbao» 内蒙古清水河县阳畔东周墓地发掘简 报 (The Excavation of Yangpan Cemetery of Eastern Zhou in Qingshuihe County, Inner Mongolia Autonomous Region). Kaogu yu wenwu 考古与文物 (Archaeology and Cultural Relics) No. 1.

6 Institute of Cultural Relics and Archaeology of Inner Mongolia Autonomous Region 内蒙古自治区文物考古研究所. 2018. «Neimenggu Qingshuihe xian Xiju mudi fajue jianbao» 内蒙古清水河县西咀墓地发掘简报 (The Excavation of Xizui Cemetery in Qingshuihe County, Inner Mongolia Autonomous Region). Kaogu yu wenwu 考古与文物 (Archaeology and Cultural Relics) No. 1
} 


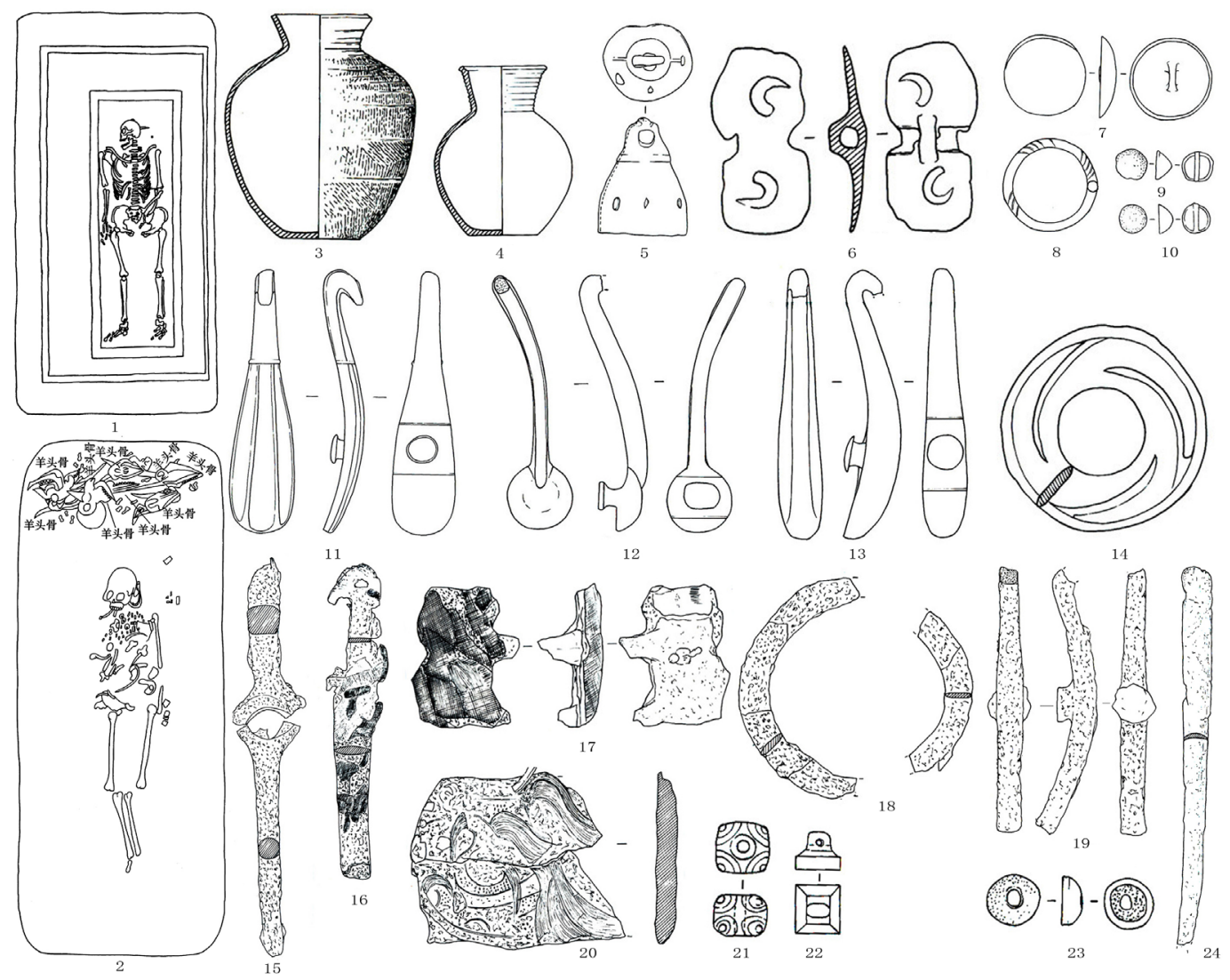

Figure 4. Line drawings of typical remains and artifacts of Shuiquan Cemetery

1. Plan view and profile of Tomb M18 2. Plan view and profile of Tomb M21 3. Guan-jar with cord pattern and bulging belly (M19:1) 4. Guan-jar with plain surface and bulging belly (M24:1) 5. Bell (M21:1) 6. Double-bird-patterned plaque (M19:2) 7, 9-10. Buckle ornaments (M21:3, M21:4, M21:5) 8. Braceletshaped ring (M18:1) 11-13. Belt hooks (M15:1, M16:1, M3:1) 14. Disc-shaped rings (M21:2) 15. Iron crane's beak axes (M23:9) 16. Iron dagger (M23:8) 17. Iron double-bird patterned plaque (M23:14) 18. Iron disc-shaped ring (M29:13) 19. Iron belt hook (M11:1) 20. Iron rectangular plaque (M23:13) 21. Liuli-glazed dragonfly eye bead (M21:16) 22. Stone seal (M18:5) 23. Bone bead (M21:14) 24. Bone nock (M19:4)

Animal sacrifices were prevalent in Xindianzi Cemetery, which were usually found from the filling dirt at the east end of the tomb and above the skull of human remains, or at the bottom of the tomb. Most of the unearthed animal remains were skulls, coronary bones, and pedal bones of horses, cattle, sheep/goats, which were placed in various ways, but most of the snouts were in the direction of human skulls; the number of animals buried in each tomb varies, with the most being at least 45, and an average of 9.8 animals per tomb. Scapulae or ribs of cattle were found placed above or on one side of the chest or abdomen of human remains, which might be a special sacrifice different from the regular one. Combinations of sacrificed animals fall into four categories, which are horses, cattle, sheep/goats; horses, sheep/goats; cattle, sheep/goats; sheep/goats. Sheep/goats account for the most. The number of cattle ranks second, followed by horses.

Most of the tombs in Xindianzi Cemetery have rich grave goods, consisting mainly of bronzes, followed by jade/stone artifacts, and the number of bone and clam artifacts is small. Only one gold arc-shaped necklace and one pottery $h u$-jar in the shape of a leather bag were unearthed. Most of the bronzes are for decoration. 


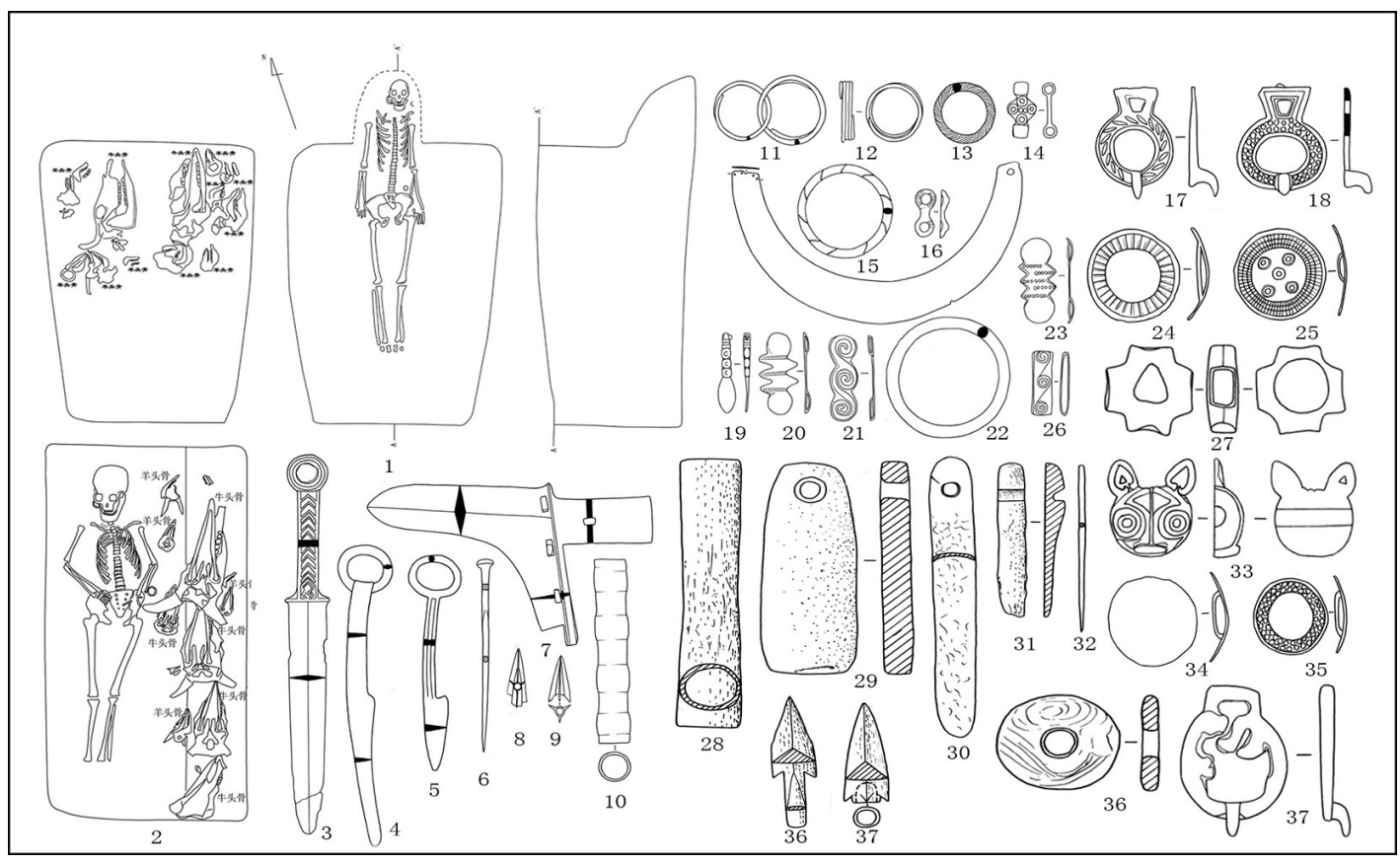

Figure 5. Line drawings of typical remains and artifacts of Xindianzi Cemetery

1. Plan view and profile of Tomb M9 2. Plan view and profile of Tomb M36 3. Dagger (99HXM41:1) 4-5. Ring pommel knives (99HXM24:1, 99HXM25:1) 6. Awl (99HXM37:1) 7. Ge-dagger-ax (99HXM5:1) 8-9. Arrowheads (99HXM41:3, 99HXM43:4) 10. Needle tube (99HXM35:4) 11-12. Earrings (99HXM26:5, 99HXM34:5) 13, 15, 22. Rings (99HXM41:3, 99HXM29:4, 99HXM41:5) 14. Pendant (99HXM10:5) 16, 20-21, 23. Linked beads (99HXM50:11, 99HXM18:10, 99HXM29:5, 99HXM41:7) 24-25, 34-35. Buckle ornaments (99HXM34:4, 99HXM3:2, 99HXM53:7, 99HXM10:7) 26. Bullet-clip-shaped ornaments (99HXM30:9) 27. Jieyue-strap crossing (99HXM37:9) 28. Bone needle tube (99HXM47:6) 29. Whetstone (99HXM3:4) 30. Bone dagger (99HXM53:7) 31. Bone nock (99HXM20:8) 32. Bone needle (99HXM47:12) 33. Tiger-head-shaped ornament (99HXM43:11) 36. Clam ring (99HXM20:24) 37. Belt buckle (99HXM41:1)

And there are a few bronze weapons, tools, and household appliances. No horse-riding equipment was found. Bronze ornaments can be divided into several categories according to their functions, including earrings, necklaces, bel, and clothing accessories. Belt accessories are the most abundant, containing ring-shaped belt buckles, linked beads, tubular ornaments, buckle ornaments, and rings. Ornaments in the form of a tiger-head and bullet-clip were also found. Among the belt accessories, the ring-shaped belt buckles worked as reamers for connecting the belt; linked beads and buckle ornaments were arranged in rows to embellish the belt; the short tubular ornaments were worn through the leather strips to form chains hanging on the belt; the number of rings at the lower end of the chain is not equal, up to 17. The most popular earrings are in spring style. Necklaces are mainly composed of ornaments in the form of a spoon, knife point, knife money handle pendant, deer, and bead. The clothing accessories are mainly made of various bronze buckle ornaments. In addition, there are bronze weapons such as ring pommel daggers, trilobate arrowheads, shortdewlap ge-dagger-axes, etc.; bronze tools such as ring pommel xiao-cutting sabers, knives with irregular holes, etc.; living utensils such as cylindrical needle tubes, awls, needles, and cross-shaped jieyue-strap-crossings.

Besides bone needle tubes, needles, and buckle ornaments, a small number of bone tubular beads, daggers, etc. were also found. Clam ornaments are fewer. Among the jade/stone artifacts, whetstones were used as tools, the rest are agate beads, turquoise beads, dressed stone beads, which were mixed and matched to form multicolored necklaces (Figure 5). 


\section{Yangpan Cemetery}

Yangpan Cemetery is located on the sunny slope of the east side of Yangpan Village, Xiaomiao Township, Qingshuihe County, Hohhot City, with a total area of about 10,000 sq.m. In 2002 and 2006, the Institute of Cultural Relics and Archaeology of Inner Mongolia Autonomous Region conducted two rescue excavations on eight tombs.

Cave tombs are dominant in Yangpan Cemetery and vertical earthen pit tombs are fewer. All of the tombs are in small and medium sizes with orientations between 19 and 75 degrees. With rectangular plan views and straight walls, the vertical earthen pit tombs have lengths between 188 and $200 \mathrm{~cm}$, widths between 60 and $65 \mathrm{~cm}$, and some of them have head niches; The cave tombs consist of two parts: the entrance corridor and the cave chamber. With rectangular plan views and straight walls, the entrance corridors have lengths between 90 and $190 \mathrm{~cm}$, widths 60 and $110 \mathrm{~cm}$. The cave chambers are generally located at the front ends of the entrance corridors and are inclined. All tombs have no burial containers. A single individual was interred supine with extended limbs, and every tomb was a primary burial. The deceased were buried with heads to the northeast, and the tomb chamber floors were mostly higher on the foot side and lower on the head side.

Animal sacrifices were prevalent in Yangpan Cemetery. They were placed in various ways, which were usually found from the filling dirt at the east end of the tomb or near the human remains at the bottom of the tomb, and some were directly placed on human remains. Most of the sacrificed animal remains were skulls, parietal bones, or pedal bones of horses, cattle, and sheep/goats, which were arranged in various ways without regularity; the number of animal sacrifices in each tomb varies from 3 to 20; The combinations of sacrificed animals fall into two categories, which are horses, cattle, sheep/goats; sheep/goats. Among them, sheep/ goats account for the most, and the number of cattle and horses is equivalent.

Besides abundant stray finds, such as bronze ring pommel swords, curved ge-daggeraxes, ring-shaped belt buckles, ring pommel knives, knives with irregular holes, discshaped rings, buckle ornaments, unearthed grave goods in Yangpan Cemetery are also rich. A large number of bronze wares in various types were discovered, including weapons such as short-dewlap ge-dagger-axes, trilobate arrowheads, etc.; tools like ring pommel xiaocutting sabers, knives with irregular holes, etc.; ornaments like ring-shaped belt buckles, rings, buckle ornaments, tubular ornaments, etc. In addition, a small number of bone belt buckles, needle tubes, needles, buckle ornaments, mabiao-horse cheek pieces were found. Other artifacts such as clam ornaments, agate beads, turquoise beads, etc. were also discovered (Figure 6).

\section{Xizuizi Cemetery}

Xizuizi Cemetery is located on the east slope of Xizuizi Village, Qingshuihe County, with an area of about 6,000 sq.m. In 2004, the Institute of Cultural Relics and Archaeology of Inner Mongolia Autonomous Region cleaned up three tombs.

The distribution of the tombs in Xizuizi Cemetery is extremely sparse. Due to serious soil erosion, the damage to the cemetery is severe. All tombs are cave tombs, which have the same burial style as the cave tombs in Yangpan Cemetery. Animal sacrifices were not found and grave goods are relatively scarce, with only a small number of artifacts of bronze, jade, stone, and clam unearthed. Besides bronze needle tubes, ring pommel knives, disc-shaped rings, tubular ornaments, the unearthed bronzes feature belt ornaments in the form of square plaques and tiger-shaped belt hooks. Cowrie shells, turquoise and crystal beads scattered around the neck should be parts of a necklace (Figure 7).

\section{(C) Huangqihai Area}

A new nomadic site was discovered in this area, namely the Baijiawan gold hoard. ${ }^{7}$

\footnotetext{
7 Institute of Cultural Relics and Archaeology of Inner Mongolia Autonomous Region 内蒙古自治区文物考古研究所. 2011. «Cha you qianqi Baijiawan jinqi jiaocang fajue jianbao» 察右前旗白家湾金器窑藏发掘简报 (The Excavation of Baijiawan Gold Hoard in Qahar Right Front Banner). Caoyuan wenwu 草原文物 (Steppe Cultural Relics) No. 1.
} 


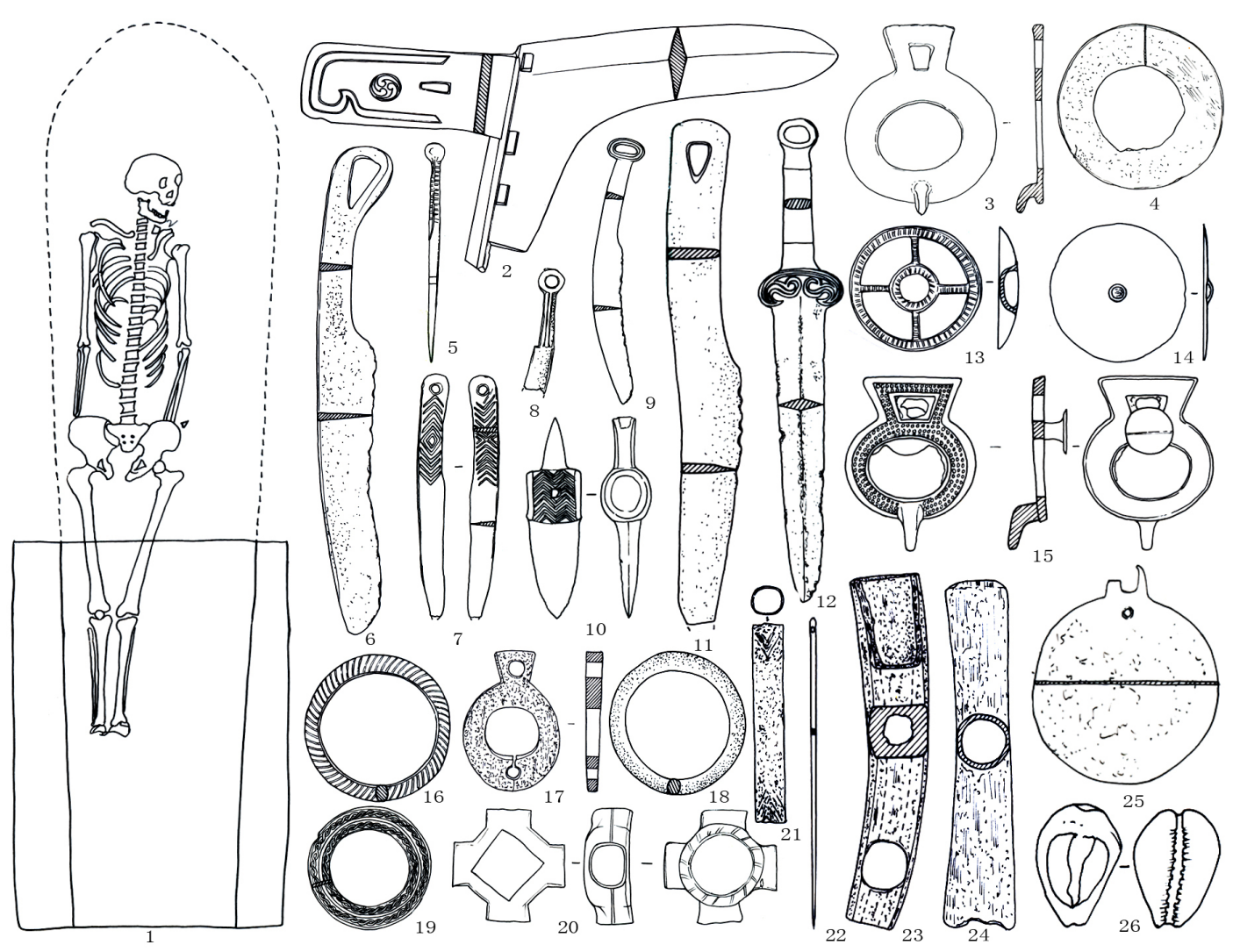

Figure 6. Line drawings of typical remains and artifacts of Yangpan Cemetery

1. Plan view and profile of Tomb M2 2. Ge-dagger-ax (M8:1) 1, 15. Belt buckle (Stray find:13, M8:3) 4, 19. Disc-shaped rings (Stray find:20, Stray find:18) 5. Awl (Stray find:37) 6-7. Knives with irregular holes (M4:1, Stray find:45) 8-9, 11. Ring pommel xiao-cutting sabers (Stray find:32, Stray find:44, M8:2) 10. Crane's beak ax (Stray find:28) 12. Dagger (Stray find:15) 1314. Buckle ornaments (Stray find:8, Stray find:27) 16, 18. Bracelet-shaped rings (M6:2, M5:4) 17. Bone belt buckle (M7:1) 20. Jieyue-strap crossing (Stray find:10) 21. Needle tube (Stray find:38) 22. Bone needle (M6:12) 23. Bone mabiao-horse cheek piece (M8:54) 24. Bone need tube (M3:7) 25. Mirror-shaped ornament (Stray find:25) 26. Cowrie shell ornaments (M5:23)

Baijiawan gold hoard is located on the southern slope of Baijiawan Village, Qahar Right Front Banner, Ulanqab City. It was discovered by local residents while digging a ditch, and 32 pieces of golden wares, turquoise ornaments, and cowrie shells were found. The gold artifacts are mainly ornaments, including square gold plaques with tiger-biting-eagle patterns, and square gold plaques with tigereating-horse patterns. The ear pendants were coiled with gold wires into cones; the necklaces were made of gold strips or composed of gold pendants, turquoise beads, and cowrie shells; a small number of round plaques with lobed edges might be used as decorations were also found (Figure 8).

(D) Ordos Area

A new nomadic site was discovered in the area, namely Shikouzi Cemetery. ${ }^{8}$

Shikouzi Cemetery is located on the second terrace of the west bank of the Yellow

\footnotetext{
8 South China Sea Archaeologiy Research Center, Sun Yatsen University 中山大学南中国海考古研究中心 and Institute of Cultural Relics and Archaeology of Inner Mongolia Autonomous Region 内蒙古自治区文物考古研究所. 2019. «Neimenggu zizhiqu Zhunge'erqi Shikouzi yizhi»内蒙古 自治区准格尔旗石口子遗址发掘简报 (The Excavation of Shikouzi Site, Jungar Banner, Inner Mongolia Autonomous Region). Wenwu chunqiu 文物春秋 (Stories of Relics) No. 1.
} 


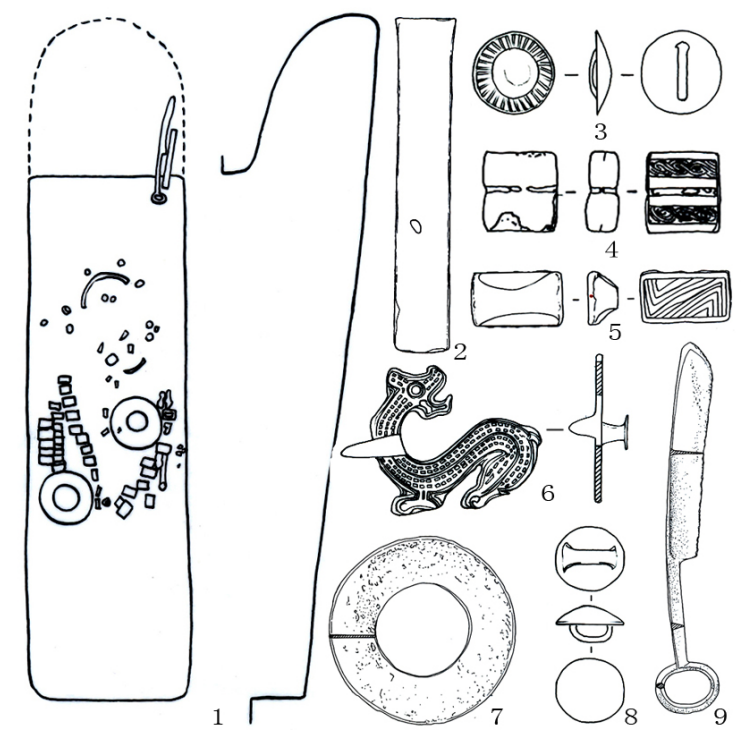

Figure 7. Line drawings of typical remains and artifacts of Xizuizi Cemetery

1. Plan view and profile of Tomb M3 2. Needle tube (M3:2) 3, 8. Buckle ornaments (Stray find: 1, 2)

4. Tubular ornaments (M3:33) 5. Square plaque (M3:40) 6. Tiger-shaped belt hook (M3:38)

7. Disc-shaped ring (M3:37) 9. Ring pommel knives (M3:1)
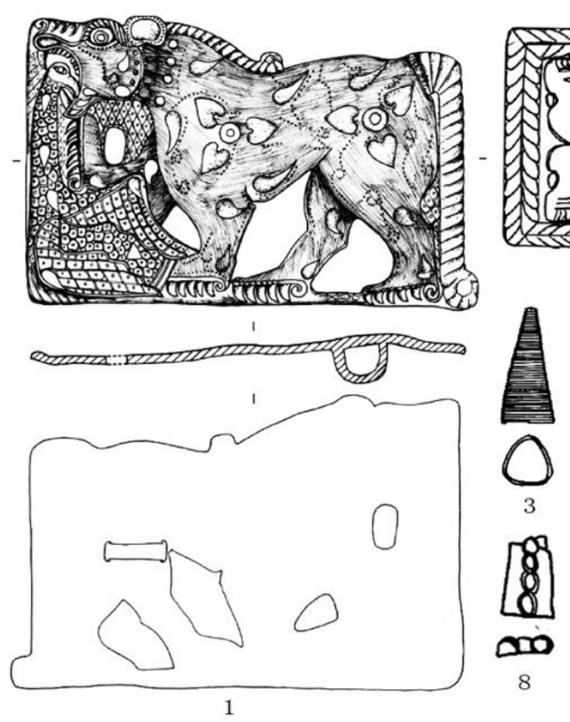
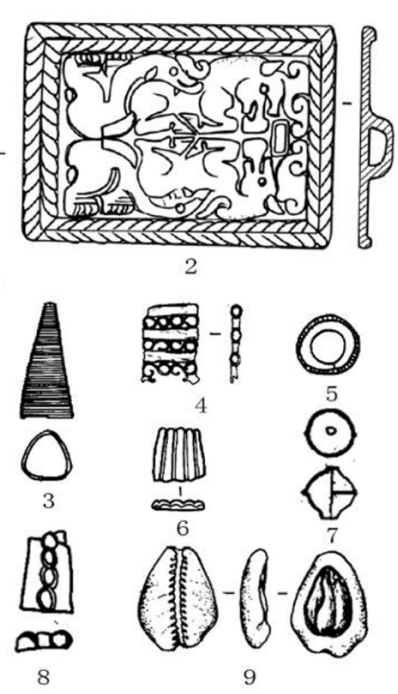
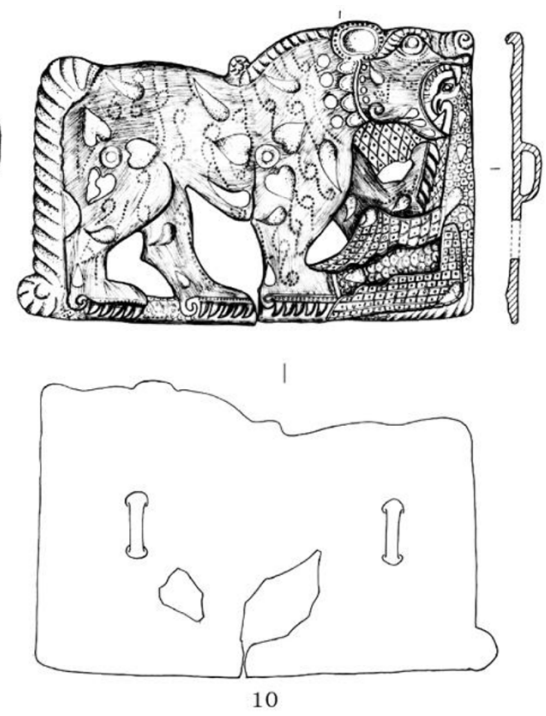

Figure 8. Line drawings of typical artifacts at Baijiawan gold hoard:

1, 10. Square plaques with tiger-biting-eagle pattern (wb:1, wb:2) 2. Square gold plaque with tiger-biting-horse pattern (wb:3) 3. Cone-shaped gold earring (wb:5) 4, 8. 8-shaped gold plaques (wb:7) 5. Round gold plaque (wb:9) 6. Corrugated gold plaque (wb:8)

7. Golden beaded pendant (wb:12) 8. Cowrie shell ornaments (wb:17) 

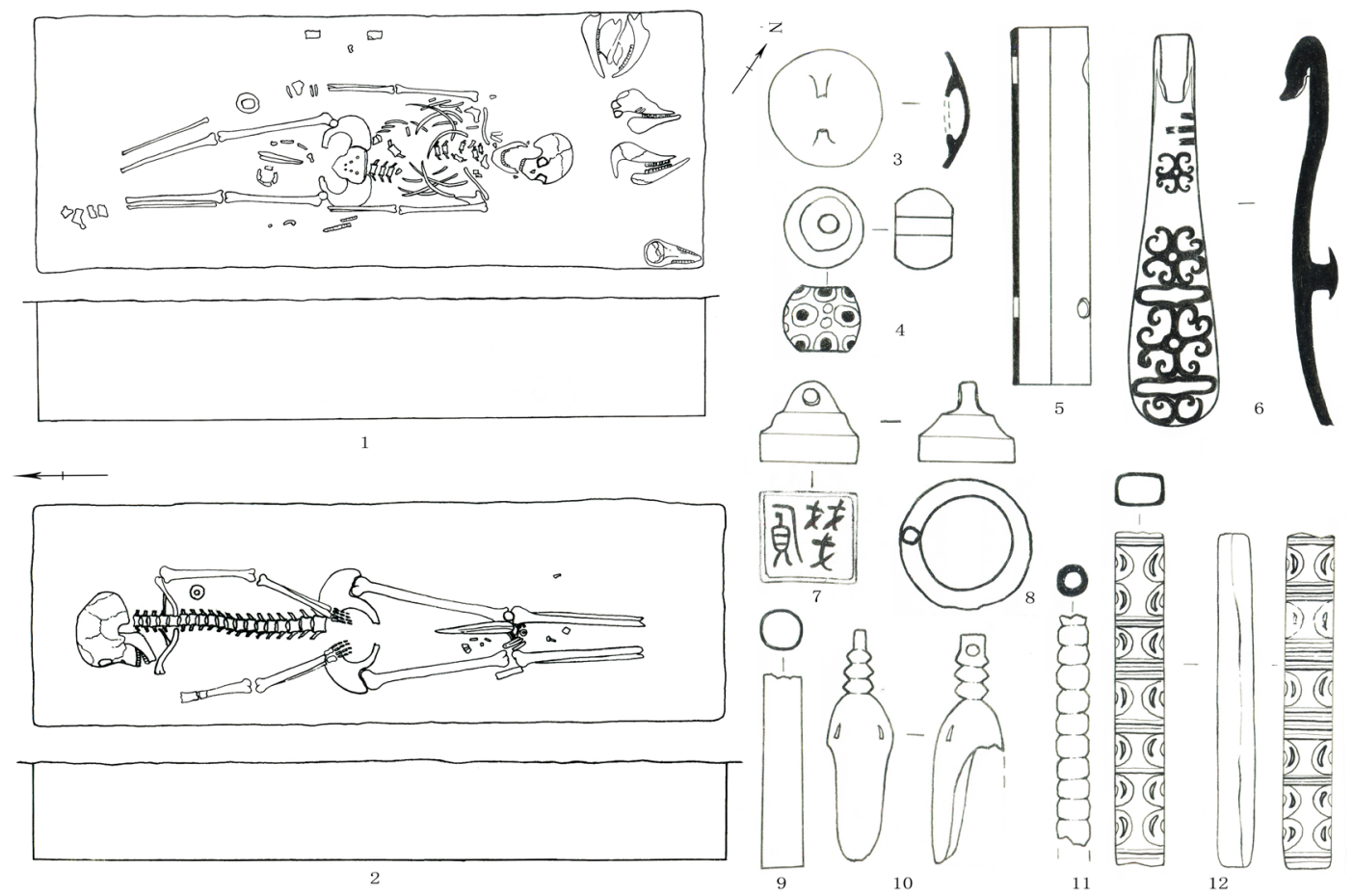

Figure 9. Line drawings of typical remains and artifacts in Shikouzi Cemetery

1. Plan view and profile of Tomb M2 2. Plan view and profile of Tomb M1 3. Buckle ornaments (M5:2) 4. Dragonfly eye bead (M1:30) 5, 12. Needle tubes (M1:8, M4:7) 6. Belt hook (M1:12) 7. Seal (M1:15)

8. Ring (M1:25) 9, 11. Tubular ornaments (M1:1, M4:6) 10. Bell (M4:8)

River in the southeast of Shikouzi Village, Jungar Banner, Ordos City, with an area of about 10,000 sq.m. In 2015 and 2018, eight rectangular vertical earthen pit tombs were discovered under two excavations. All tombs were primary burials with single interment. Each individual was laid out in an extended supine position. According to the burial style and combinations of grave goods, these tombs can be divided into two types: A and B.

Shikouzi Cemetery is dominated by eastward Type A tombs. Animal sacrifices were placed at the bottom of the tomb pit and in front of the human skull. The main types are the skulls or pedal bones of cattle and sheep/goats, which were placed upside down or in sideways. The snouts were placed in the direction of human skulls; the number of sacrifices is different, and the maximum number is four; the combinations of sacrificed animals can only be divided into two categories: cattle, sheep/goats; sheep/goats. The latter are dominant. Iron ar- tifacts are the main grave goods, including daggers, rings, xiaodao-cutting sabers, awls; a small number of bronzes were also found, such as needle tubes, waist bells, buckle ornaments, earrings, etc. There are very few Type B tombs in Shikouzi Cemetery. The tombs are northward and no animal sacrifices were discovered. Unearthed grave goods consist of bronze belt hooks, «Han Cheng» seals, "Qianfu» seals, tubes, etc.; bone hairpins, buckle ornaments, $x i$-bodkins and so on; ornaments such as crystal rings, crystal beads, liuli-glazed dragonfly eye beads, agate beads and the like (Figure 9).

\section{The study of related academic issues}

The eight early nomadic cultural remains newly discovered in the middle section of the Inner Mongolia Great Wall area are roughly dated to the Eastern Zhou dynasty, which is equivalent to the late Spring and Autumn to the late Warring States period. Although there is no $14 \mathrm{C}$ data for reference, according to changes 
in cultural connotations, the above-mentioned remains can be divided into two development phases. The grave goods unearthed in the cemeteries of Xinzhouyaozi, Xiaoshuanggucheng, Xindianzi, Yangpan, and Xizuizi are mainly bronzes. Central Plains style ge-dagger-axes of the late Spring and Autumn period to the early Warring States period were unearthed from two of the cemeteries. Therefore, the above five cemeteries can be classified into the early stage, dated to the late Spring and Autumn period to the early Warring States period, from the sixth century BCE to the fifth century BCE; the cultural connotation of Baijiawan gold hoard is similar to the Aluchaideng site, ${ }^{9}$ and should be dated to the late Warring States period. The grave goods unearthed from Shuiquan Cemetery and Shikouzi Cemetery are mainly ironware, and the date is late. In addition, Type B tombs coexisting with them are not earlier than the early Warring States period. Therefore, the above three remains can be classified into the late stage, and dated to the middle and late Warring States period, i. e., from the fourth century to the third century BCE.

At present, scholars generally believe that ${ }^{10}$ the early nomadic cultural remains in the middle section of the Great Wall area in Inner Mongolia can be roughly divided into Maoqinggou culture in Manhan Mountain area, Taohongbala culture in Ordos area and Xiyuan type in the south foothill of Daqing Mountain. The cultural connotation of Xinzhouyaozi, Xiaoshuanggucheng, Shuiquan, and Shikouzi cemeteries have more commonalities with Maoqinggou Cemetery, ${ }^{11}$ which can be classified into Maoqinggou culture. However, the differences between Xinzhouyaozi and

\footnotetext{
9 Tian, Guangjin 田广金, and Suxin Guo 郭素新. 1986. «Aluchaideng faxian de jinyinqi» 阿鲁柴登发现的金银器 (The Gold and Silver Wares Found at Aluchaideng). In E'erduosi shi qingtongqi 鄂尔多斯式青铜器 (Ordos Bronzewares). Wenwu chubanshe, Beijing.

${ }^{10}$ Yang, Jianhua 杨建华. 2005. Dongzhou shiqi beifang xi qingtongqi wenhua muzang bijiao yanjiu 东周时期北方系青 铜器文化墓葬比较研究 (A Comparative Study of the Bronze Cultural Tombs of the Northern System in the Eastern Zhou Dynasty). Kexue chubanshe, Beijing.

${ }_{11}$ Tian, Guangjin 田广金, and Suxin Guo 郭素新. 1986. «Maoqinggou mudi» 毛庆沟墓地 (Maoqinggou Cemetery). In E'erduosi shi qingtongqi 鄂尔多斯式青铜器 (Ordos Bronzewares). Wenwu chubanshe, Beijing.
}

Xiaoshuanggucheng are very obvious. For example, vertical earthen pit tombs are prevalent in Xinzhouyaozi Cemetery, and animal sacrifices were placed upside down, and there are swine and dogs that demonstrate agricultural economic factors in addition to horses, cattle and sheep/goats; pottery vessels feature sharp shoulders; bronzes especially belt ornaments mainly consist of ring-shaped belt buckles, double/single bird-shaped plaques, and linked beads. In contrast, cave tombs with side chambers are dominant in Xiaoshuanggucheng Cemetery; most of the animal sacrifices are horses, cattle, and sheep/goats, and swine and dogs were not discovered, which showed typical nomadic economic characteristics; pottery wares with bulging bellies are popular; tiger-shaped belt ornaments and double-birdpatterned plaques are the basic combinations. The significant differences between the above two cemeteries resulted from different cultural sources instead of different periods or disparate societies.

Maoqinggou Cemetery has dual cultural factors of Xinzhouyaozi and Xiaoshuanggucheng. The remains similar with Maoqinggou Cemetery are dominant in Manhan Mountain area. Arguably, Maoqinggou culture should be the product of the combination and interaction of the two cultural factors represented by Xinzhouyaozi Cemetery and Xiaoshuanggucheng Cemetery. The cultural connotations of Shuiquan Cemetery and Shikouzi Cemetery are similar and can be dated to the late stage of Maoqinggou culture. Shuiquan Cemetery was distributed in the Manhan Mountain area and Shikouzi Cemetery was distributed in the northeastern part of the Ordos area. This phenomenon seems to indicate that Maoqinggou culture began to move southward and cross the Yellow River at the latest in the fifth to fourth centuries $\mathrm{BCE}$, and expanded its distribution area.

Although the burial style of Xindianzi Cemetery is different from the Yangpan and Xizuizi cemeteries, they share more cultural commonalities from the perspective of grave goods. Since they are located in the Hunhe River basin, and collectively reflect the unique regional cultural characteristics, therefore, the above three cemeteries can be classified into 
the same archaeological culture type, named as the Xindianzi type. Baijiawan gold hoard, Aluchaideng gold and silver ware group distributed in the Ordos region, and the Warring States Xigoupan Cemetery ${ }^{12}$ shared similar cultural characteristics and can be classified as the same cultural remains. Its distribution area may have extended beyond the middle section of Great Wall area in Inner Mongolia.

The early nomadic remains in the middle section of the Inner Mongolia Great Wall area existed in the early stages of the sixth century to the fifth century BCE. They can be divided into four cultural remains: Maoqinggou culture, Taohongbala culture, Xiyuan type, and Xindianzi type. The remains entered the fourth to third century BCE can only be divided into two types, represented by Maoqinggou culture and Baijiawan gold hoard. At present, there is no obvious boundary between the two types of remains. The reason to explain this needs more archaeological data.

Taohongbala culture, Maoqinggou culture, Xiyuan type, and Xindianzi type have different distribution areas in the early stage of the sixth to the fifth century BCE. However, after a detailed analysis of their cultural connotations, they can be divided into two different cultural systems. The distribution area of Taohongbala culture is different from the Maoqinggou culture, but there are many commonalities. For example, vertical earthen pit tombs were popular in both cemeteries; pottery wares were discovered as grave goods; unearthed weapons mainly consist of swords with sophisticated patterns of double-birds-looking-back, and bird-and-tiger. In contrast, the tombs of Xiyuan type and Xindianzi type are popular with cave tombs with side chambers and regular cave tombs; pottery wares were not buried as grave goods; ring pommel swords were the main weapons; animal patterns were not often seen. The different cultural connotations of the above two cultural systems should result from different degrees of absorbing disparate cultural factors.

\footnotetext{
${ }^{12}$ Yeke Joo League Cultural Relics Workstation 伊克昭盟文 物工作站, and Cultural Relics Task Force of Inner Mongolia Autonomous Region 内蒙古文物工作队. 1980. «Xigoupan xiongnu mu» 西沟畔匈奴墓 (The Xiongnu Tombs at Xigoupan). Wenwu 文物 (Cultural Relics) No. 7.
}

The cave tombs with side chambers and regular cave tombs dominant in Xiyuan type and Xindianzi type were originated from the Guanzhong area in Shaanxi and the southern part of the Great Wall of Inner Mongolia ${ }^{13}$ but not continued. Instead, they have a clear development course in Gansu-Qinghai region. ${ }^{14}$ Archaeological findings indicate that after the sixth century $\mathrm{BCE}$, the two types widely distributed in the Shajing culture in central Gansu Province ${ }^{15}$ and the Yanglang culture in Longshan area $^{16}$ were used as a cultural factor to spread from west to east along the Yellow River, and first arrived at the Tumochuan Plain in the southern foothills of Daqing Mountain, and then spread eastward to Manhan Mountain and the Hunhe River Basin. The head niches with pottery wares widely used in Xinzhouyaozi Cemetery was a new cultural phenomenon, which may be influenced by cave tombs. The knife money handle pendants in Xindianzi Cemetery, and the tiger-shaped belt hooks in Xizuizi Cemetery have obviously

\footnotetext{
${ }^{13}$ Shaanxi Provincial Institute of Archaeology 陕西省考古 研究院等 et al. 2018. «Shaanxi Gaoling Yangguanzhai yizhi Miaodigou wenhua mudi fajue jianbao» 陕西高陵杨官寨遗 址庙底沟文化墓地发掘简报 (The Excavation of Miaodigou Cultural Cemetery at the Yangguanzhai Site, Gaoling District, Shaanxi Province). Kaogu yu wenwu 考古与文物 (Archaeology and Cultural Relics) No. 4.

${ }^{14}$ Cao, Jianen 曹建恩, and Jinsong Sun 孙金松. 2008. «Zhongguo beifang diqu Dongzhou Xihan shiqi pian dongshimu yanjiu» 中国北方地区东周西汉时期偏洞室墓研究 (Study on the Cave Tombs with Side Chambers in the Eastern Zhou Dynasty in the Western Han Dynasty in North China). In Zhongguo shi yanjiu 中国史研究 (Chinese History Research) (Korea), Vol. 53.

${ }^{15}$ Gansu Provincial Institute of Cultural Relics and Archaeology 甘肃省文物考古研究所. 2001. Yongchang Xigang Chaiwangang - Shajing wenhua muzang fajue baogao 永昌 西岗柴湾岗一沙井文化墓葬发掘报告 (Xigang and Chaiwangang in Yongchang County: The Excavation of the Tombs of the Shajing Culture). Gansu renmin chubanshe, Lanzhou.

${ }^{16}$ Ningxia Institute of Cultural Relics and Archaeology 宁夏 文物考古研究所, and Guyuan Museum 固原博物馆. 1993. «Ningxia Guyuan Yanglang qingtong wenhua mudi» 宁夏 固原杨郎青铜文化墓地 (The Yanglang Bronze Age Culture Cemetery of Guyuan County, Ningxia Hui Autonomous Region). Kaogu xuebao 考古学报 (ACTA Archaeologica Sinica) No. 1;

Ningxia Institute of Cultural Relics and Archaeology 宁夏文 物考古研究所. 1995. 《Ningxia Pengpu Yujiazhuang mudi» 宁夏彭堡于家庄墓地 (The Yujiazhuang Cemetery at Pengpu Township, Ningxia Hui Autonomous Region). Kaogu xuebao 考古学报 (ACTA Archaeologica Sinica) No. 1.
} 
been influenced by the Yuhuangmiao culture. ${ }^{17}$ The popular sun radiant pattern on the buckle ornament surfaces unearthed from Xindianzi Cemetery can be traced back to the upper Xiajiadian culture. ${ }^{18}$ All of these indicate that the formation of the early nomadic cultural remains in the middle section of the Inner Mongolia Great Wall area was influenced by the archaeological culture of the eastern section of the Great Wall area in Inner Mongolia. Throughout the Inner Mongolia Great Wall area, the culture spread from west to east was more intense, and there is no sufficient evidence to prove that this cultural communication has signs of mass human migration.

Archaeological findings indicate that the mirrors with handles unearthed in Xinzhouyaozi Cemetery have a wide distribution in the middle section of the Great Wall area in Inner Mongolia, but its origin can be traced back to the Eurasian steppe in the north; the most popular bird-shaped plaques and double-bird patterned plaques in the Manhan Mountains and Ordos area were also discovered a small amount in Mongolia and Zabaykalsky Krai in Russia. Gold plaques with tiger-biting-horse pattern having the tiger hind legs twisted were discovered at Baijiawan gold hoard, meanwhile, this pattern was mainly found in Pazyryk culture. ${ }^{19}$

\footnotetext{
${ }^{17}$ Beijing Municipal Institute of Cultural Relics 北京市文 物研究所. 2007. Jundushan mudi - Yuhuang miao 军都山 墓地一玉皇庙 (Jundu Mountain Cemetery - Yuhuangmiao). Wenwu chubanshe, Beijing.

${ }^{18}$ Institute of Cultural Relics and Archaeology of Inner Mongolia Autonomous Region 内蒙古自治区文物考古研究所 et al. 2009. Xiaoheishigou: Xiajiadian shangceng wenhua yizhi fajue baogao 小黑石沟: 夏家店上层文化遗址发掘报告 (Xiaoheishigou: The Excavation of the Upper Xiajiadian Culture). Kexue chubanshe, Beijing.

${ }_{19} \mathrm{Wu}$ En Yue Si Tu 乌恩岳斯图. 2007. Zhongguo caoyuan kaoguxue wenhua yanjiu - Qingtong shidai zhi zaoqi tieqi shidai 中国草原考古学文化研究—青铜时代至早期铁器时 代 (Chinese Steppe Archaeology Culture Research - Bronze Age to Early Iron Age). Kexue chubanshe, Beijing;

Wu En Yue Si Tu 乌恩岳斯图. 2008. Beifang caoyuan kaoguxue wenhua bijiao yanjiu - Qingtong shidai zhi zaoqi xiongnu shiqi 北方草原考古学文化比较研究一青铜时代 至早期匈奴时期 (Comparative Study of Northern Grassland Archaeology Culture - Bronze Time to Early Xiongnu Period). Kexue chubanshe, Beijing; В. Д. КУбарев (V.D. Kubarev). 1987. КУрганЫ УДанДЫКа (Kurgan Udandyk). НовоСИБ ирСК (Novosibirsk); В. Д. КУбарев (V.D. Kubarev). 1992. КУрганЫ СаиДогема (Kurgan Saidogema). Ново СибирСК (Novosibirsk);
}

Arguably, the middle section of the Great Wall area of Inner Mongolia and the Eurasian steppe share certain cultural commonalities, which indicate that there were also quite close cultural links between the two regions. Through the physical anthropological appraisal of human remains discovered at Xinzhouyaozi, Xiaoshuanggucheng, and Xindianzi cemeteries, it is found that some human remains in Xinzhouyaozi and Xiaoshuanggucheng possess the physical characteristics of «the ancient Mongolian Plateau people,,$\rangle^{20}$ while all the human remains in Xindianzi Cemetery are having the physical characteristics of the «ancient Mongolian Plateau people.» This type of population with the characteristics of «more rounded head, narrower frontal bone, broader parietal bone, and flatter face» appeared on a large scale in the middle section of the Great Wall area in Inner Mongolia, indicating that people frequently move southwards in the eastern part of the Eurasian steppe around the sixth century BCE. The south-north migration strengthened the cultural communication between the middle section of the Great Wall area of Inner Mongolia and the Eurasian steppe. Considering the development of the common cultural factors in the two regions, it can be concluded that in the early stage of the sixth century to fifth century BCE, the middle section of the Great Wall area of Inner Mongolia has extensive cultural contact with the Eurasian steppe. The cultural connection with the eastern Eurasian steppe has been accompanied by human migration. And

\footnotetext{
${ }^{20}$ Zhang, Quanchao 张全超. 2006. Neimenggu Helinge'er xian Xindianzi mudi rengu yanjiu 内蒙古和林格尔县新店 子墓地人骨研究 (Study on Human Remains in Xindianzi Cemetery in Horinger County, Inner Mongolia Autonomous Region). Kexue chubanshe, Beijing;

Institute of Cultural Relics and Archaeology of Inner Mongolia Autonomous Region 内蒙古自治区文物考古研究所. 2009. «Neimenggu Liangcheng xian Xinzhouyaozi mudi fajue jianbao» 内蒙古凉城县忻州窑子墓地发掘简报 (The Excavation of Xinzhouyaozi Cemetery in Liangcheng County, Inner Mongolia Autonomous Region). Kaogu 考古 (Archaeology) No. 3.;

Institute of Cultural Relics and Archaeology of Inner Mongolia Autonomous Region 内蒙古自治区文物考古研究所. 2009. «Neimenggu Liangcheng xian Xiaoshuanggucheng mudi fajue jianbao» 内蒙古凉城县小双古城墓地发掘简报 (The Excavation of Xiaoshuanggucheng Cemetery in Liangcheng County, Inner Mongolia Autonomous Region). Kaogu 考古 (Archaeology) No. 3 .
} 
in the late stages of the fourth to third centuries BCE, the middle section of the Great Wall area in Inner Mongolia was more influenced by the culture of the western Eurasian steppe.

The most representative pottery wares with bulging bellies and cord patterns in Xiaoshuanggucheng Cemetery and Shuiquan Cemetery should be derived from Ximaqing type ${ }^{21}$ the pottery wares with cord patterns and sharp shoulders in Xinzhouyaozi Cemetery can be traced back to the Western Zhou culture; the Central Plain style gedagger-axes unearthed from Xindianzi and Yangpan cemeteries are derived from the Jin and Zhao culture; the large tiger-biting-eagle plaques with two sets of Central Plains floral patterns on tiger unearthed from Baijiawan

${ }^{21}$ Cao, Jianen 曹建恩. 2006. «Neimenggu zhongnanbu Shang Zhou kaogu xinjinzhan» 内蒙古中南部商周考古新进 展 (New Progress in Shang and Zhou Archaeology in Central and Southern Inner Mongolia Autonomous Region). Neimenggu wenwu kaogu 内蒙古文物考古 (Inner Mongolia Cultural Relics and Archaeology) No. 1. should be made by artisans from Central Plains. It can be seen that the early nomadic culture in the middle section of the Great Wall area in Inner Mongolia has extensively absorbed the cultural factors of the Central Plains. In addition, the burials in Shuiquan Cemetery, as well as Shikouzi Cemetery, can be classified into two types (Type A and Type B). The Type B tombs should be the people who migrated from the Central Plains to the north. After arriving, this group of people continued to operate agriculture and played important roles in the stable development of local nomadic economy. Overall, we can see that both the spread of cultural factors and human migration existed through the cultural exchanges between the north and south of the Great Wall area. This phenomenon continues to occur during the formation and development of early nomadic remains, greatly promoting the integration of agrarian and pastoral cultures, and enriched the cultural connotation of the region. 